\title{
Jesaja 36-39 - Sinkroniese en diakroniese lees van 'n teks
}

J H le Roux \& S I Cronjé

(Universiteit van Pretoria)

\section{ABSTRACT}

\section{Isaiah 36-39 - Sinchronic and diachronic reading of a text.}

There has been growing interest in the book of Isaiah, particularly with regard to the unity of the book. The current debate has grown out of the discontent of more and more researchers with the historical-critical methods and their results. The classical tripartition of Duhm, and especially his supporters' application of it, is being queried. The unity of all 66 chapters of Isaiah is indicated as an alternative. The synchronic and diachronic approaches to the text are often played off against each other. An attempt is made to raise questions about both perspectives, showing that each approach has its shortcomings. However, by looking at the text from a diachronic as well as a synchronic perspective, an improved view of the rich variety of the text can be seen. In this article, Isaiah 36-39 serves as an illustration.

\section{INLEIDING}

Hierdie artikel wil 'n bydrae lewer tot die debat wat handel oor die keuse tussen 'n sinkroniese of 'n diakroniese benadering tot die teks van die Hebreeuse Bybel. Jesaja 36-39, wat as deel van die ondersoek in my proefskrif $^{1}$ geëksegetiseer is, word hier as vertrekpunt geneem én ter illustrasie gebruik.

Dié twee perspektiewe, te wete 'n sinkroniese en diakroniese perspektief op die teks, het nie alleen in die geskiedenis van $\mathrm{Ou}$ Testamentiese navorsing in Suid-Afrika 'n belangrike rol gespeel in die eksegetiese debat nie (vgl Le Roux 1993), maar is steeds op SuidAfrikaanse Ou-Testamentici se tafels. Wat die onlangse verlede betref, kan byvoorbeeld die artikels van onder andere Deist (1995), Snyman (1996) en Human (1999) vermeld word. In elkeen van genoemde artikels kom die saak van 'n sinkroniese en 'n diakroniese benadering tot die teks, weliswaar op 'n eie manier by elkeen, aan die orde.

Ook op internasionale gebied is hierdie debat nog nie afgehandel nie. Het Oudtestamentisch Werkgezelschap in Nederland en Belgie en The Society for Old Testament Study se negende kongres in 1994 gehou te Kampen het byvoorbeeld as tema gehad "Synchronic or Diachronic? - A Debate on Method in Old Testament Exegesis”.

\footnotetext{
${ }^{1}$ Hierdie artikel is gebaseer op navorsing van Cronjé wat in 2002 uitgeloop het op 'n proefskrif getiteld Jesaja net een boek? Die pendulum swaai terug, wat aan die Universiteit van Pretoria aanvaar is.
} 
Wat die keuse van Jesaja 36-39 betref, kan ter motivering vermeld word dat daar reeds vir ten minste die laaste drie dekades 'n oplewing in Jesaja-navorsing bestaan. Dit het onder andere gelei tot die organisering van die sogenaamde The Formation of the Book of Isaiah Seminar of the Society of Biblical Literature, onder voorsitterskap van Marvin Sweeney en Roy Melugin (Melugin \& Sweeney 1996:13). Daarby is die boek Jesaja in sy geheel 'n komplekse boek wat roep om toeligting vanuit meer as een perspektief. Clements (1985:98) maak in dié verband die opmerking dat "It is, I firmly believe, one of the most complex literary structures of the entire Old Testament".

Trouens, dit kan by Clements se opmerking gevoeg word dat die boek Jesaja se wordingsgeskiedenis in kompleksiteit waarskynlik vergelyk kan word met dié van die Pentateug. Die gevolg is dat dit nie so eenvoudig is om te bepaal presies wanneer watter stof in die redaksionele proses geherinterpreteer en bygewerk is, watter stof van Jesaja self afkomstig en watter die werk van latere redaktor(s) is, asook wie nou eintlik die gehoor is op wie die boodskap gemik is, en wat presies die funksie en boodskap van die boek is nie. Iets van hierdie literêre kompleksiteite blyk ook uit die magdom literatuur wat oor die afgelope dekades in verband met die boek Jesaja gepubliseer is.

\section{NAVORSINGSGESKIEDENIS VAN DIE BOEK JESAJA}

Weens 'n gebrek aan ruimte word hier slegs 'n bondige oorsig gegee van die belangrikste strominge binne die Forschungsgeschichte van die boek Jesaja sedert die Middeleeue tot en met die laaste dekade van die 20ste eeu.

Die boek Jesaja is anvanklik van begin tot einde beskou as die werk van een outeur, te wete die agste-eeuse profeet Jesaja. Die boek, op grond van dié outeurskap, sou 'n eenheid vorm. Met die koms van die Aufklärung is bogenoemde standpunt vervang deur die standpunt dat die boek in sy geheel nie die werk van die agste-eeuse profeet is nie, maar dat daar slegs 'n beperkte aantal logi Esaias in 1-39 voorkom, terwyl 40-55 uit die eksiliese tyd en daarna dateer en 56-66 uit die Persiese tyd. Met ander woorde, waar die boek aanvanklik gesien is as 'n eenheid omrede

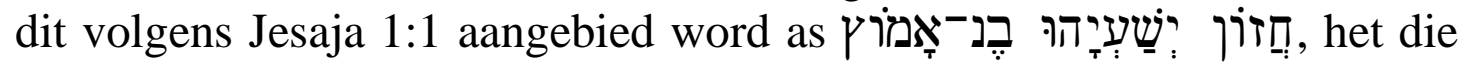
histories-kritiese navorsing, met sy klem op die historiese konteks van die teks in sy onderskeie stadiums van ontwikkeling, daartoe aanleiding gegee dat Jesaja nou nie meer as 'n eenheid gesien is nie, maar as die werk van ten minste twee, maar waarskynlik drie "Jesajas" wat in drie verskillende tye en plekke opgetree het, en dat daar gevolglik nie sprake van eenheid in die boek is nie. 
Gedurende die tweede helfte van die 20ste eeu het daar 'n verskuiwing plaasgevind weg van die historiese na die tekstuele, en uiteindelik ook na die hedendaagse leser. Van 'n diakroniese benadering is daar dus beweeg na 'n sinkroniese benadering tot die teks. Hierdie wegbeweeg van die historiese konteks na die teks se literêre en kanoniese konteks, en uiteindelik na die konteks van die hedendaagse leser, het gestalte gevind in benaderings soos strukturalisme, retoriese kritiek, die kanoniese benadering, en nuwere literêre benaderings soos feminisme en resepsiekritiek (Exum \& Clines 1993:15-20).

Met ander woorde, waar die histories-kritiese navorsing wegbeweeg het van 'n eenheid van die boek Jesaja, gaan hierdie nuwe bewegings weer terug na 'n eenheid binne die boek Jesaja. Nou lê die eenheid egter nie meer opgesluit in outeurskap nie, maar in die teks. Voorstaanders van hierdie benaderings neem, soos die voor-histories-kritiese navorsers, ook

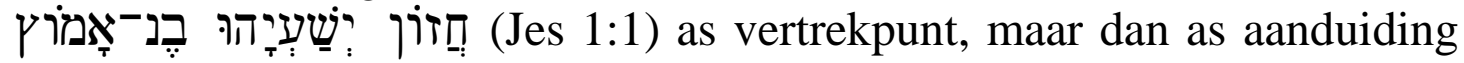
van die Gattung van die hele boek (bv Watts 1985:xxvii-xxxii), of as argument dat Jesaja 1:1 as opskrif geld vir die hele boek (bv Sweeney 1988:101) en dat die boek Jesaja se redaktor(s) dus bedoel het dat dit in sy geheel as eenheid gelees moet word. Volgens voorstaanders van hierdie benaderings bied Jesaja 1:1, saam met die laaste hoofstukke van die boek, ook 'n aanduiding van wie die gehoor is tot wie die boodskap van Jesaja, soos ons dit vandag voor ons het, gerig is (bv Watts 1985 en Sweeney 1988).

Deur die uitwys van intertekstuele relasies word die boek in sy geheel gevolglik gesien as tekstuele eenheid waarvoor 'n finale redaktor of redaktors verantwoordelik was. Hierdie finale redaktor(s) het doelbewus sulke strukture en/of relasies in die teks ingebou sodat dit as eenheid deur sy/hulle gehoor gelees/gehoor moes word. Hierdie strukture en/of relasies kan met behulp van die nuwere benaderings ontsluit word, en die funksie en boodskap van die teks sodoende vasgestel word. Dus, in die lig van hierdie strukture, relasies en uiteindelike hoorders/lesers van die sogenaamde finale teks van Jesaja, word die boek dan nou in sy geheel as literêre eenheid geïnterpreteer. Almal is dit egter nie eens oor die moontlikheid om die gehoor aan wie Jesaja as geheel gerig is te bepaal nie, en verkies om die klem te verskuif na die hedendaagse leser (vgl bv Conrad 1991:156 en Darr 1994:225 ev).

\section{HISTORIESE PERSPEKTIEF}

$\mathrm{Na}$ die bondige oorsig van die huidige stand van die Forschungsgeschichte in Jesaja-navorsing, verskuif die aandag vervolgens na die teks self. As gevolg van die omvang van die boek Jesaja, moes daar in die proefskrif noodwendig 'n seleksie gemaak word en is gekies om met Jesaja 36-39, maar dan met toespitsing op Jesaja 38- 
39, te werk. Hoewel daar in die detail-eksegese byna uitsluitlik op Jesaja 38 en 39 gefokus is, het die historiese ondersoek Jesaja 36-39 in die geheel hanteer. Enersyds is dit gedoen omrede Jesaja 36-39 as een verhaal aangebied word; andersyds omrede, soos nou reeds by meer as een geleentheid aangetoon is, die redaktor(s) sowel Jesaja 38 as Jesaja 39 binne die historiese raamwerk van Sanherib se beleg van Jerusalem plaas.

Met Jesaja 36:1 word die leser deur die teks verplaas na sowat die laaste dekade van die agste eeu vC, en daarom moet die leser hom/haar vergewis van omstandighede in die Ou Nabye-Ooste gedurende dié tyd. Met die raadpleeg van sowel die primêre bronne (Jes 36-39, 2 Kon 18-20, 2 Kron 29-31, Sirag 48:17-25 en die Assiriese berigte en muurpanele van Sanherib se derde veldtog na Palestina) as die sekondêre bronne (geskiedenisse van Israel, kommentare, monografieë en inleidings op die Ou Testament) ${ }^{2}$, kom die navorser onder die indruk dat Jesaja 36-39, soos die Assiriese bronne, alleen maar 'n weergawe van gebeure gedurende dié tyd verteenwoordig en dat die Ou-Testamentiese weergawe teologies gelaai is, sodat die gebeure waarvan vertel word op 'n heel bepaalde manier gehoor moes word. Om dit te bereik, is die geskiedenis rondom bepaalde insidente gedurende koning Hiskia van Juda se regeringstyd op 'n bepaalde manier en in 'n heel spesifieke volgorde weergegee ${ }^{3}$.

So byvoorbeeld wys 'n historiese ondersoek duidelik uit dat die gebeure waarna Jesaja 38 en 39 verwys kronologies vóór dié van Jesaja 36-37 hoort. Daar is byvoorbeeld in Jesaja 38:6 die verwysing na die toekomstige verlossing van die stad Jerusalem uit die mag van die Assiriërs. Daarby word gebeure wat oor 'n lang tyd plaasgevind het, vertel asof alles min of meer in dieselfde tyd gebeur het. Hier dink 'n mens byvoorbeeld aan Sanherib se dood, wat op so 'n wyse aangebied word dat dit die indruk by die leser skep dat hy pas na sy terugkeer van sy derde veldtog na Palestina vermoor is.

Wat die primêre bronne betref, is dit egter nie alleen die OuTestamentiese weergawes wat verskil van dié van die Assiriese weergawes nie. Die Ou-Testamentiese bronne verskil ook onderling. Die twee mees voor die hand liggende voorbeelde is waarskynlik die ontbreking van die sogenaamde Hiskiapsalm (Jes 38:9-20) in die Konings weergawe, terwyl Jesaja 36-39 die betaling van tribuut deur koning Hiskia aan die Assiriese koning, Sanherib, verswyg (2 Kon 18:14-16).

Op grond van bogenoemde en nog ander navorsingsresultate, wat weens beperkte ruimte nie hier weergegee kan word nie, word die afleiding gemaak dat dit nie die bedoeling van die redaktor(s) was dat

\footnotetext{
2 'n Verwysing na elk van hierdie sekondêre bronne sal die literatuurverwysing aan die einde van hierdie studie te groot in omvang maak.

${ }^{3}$ Dat ook die Assiriese bronne ideologies gelaai is, word in my proefskrif duidelik aangetoon.
} 
Jesaja 36-39 as historiese dokument gelees moet word nie. Die betekenis van die teks moet gevolglik op 'n ander vlak gesoek word. Die feit dat Jesaja en 2 Konings se weergawes van mekaar verskil, beteken verder dat elkeen van dié tekste in die konteks van hulle onderskeie literêre Sitze-imLeben gelees moet word (vgl bv Kasher 2001 se artikel in dié verband).

\section{LITERÊRE PERSPEKTIEF}

Na die toeligting van die teks vanuit 'n historiese perspektief, word daar vervolgens vanuit 'n literêre perspektief op die teks gefokus. Die bestudering van die teks binne sy literêre konteks en na sy literêre aard, bevestig genoemde afleiding wat op grond van die historiese ondersoek gemaak is. Die teks vorm 'n duidelik afgebakende eenheid (Wildberger 1982:1374 en Sweeney 1996:454) wat na sy Gattung as narratiewe teks getipeer kan word. Daar is in Jesaja 36-39 'n duidelike aanduiding van tyd, ruimte, opeenvolging van gebeure en karaktertekening (vgl bv Alter 1981 en Brink 1987 vir die belang hiervan by die identifisering van tekste as narratief). Jesaja 36-39 neem enkele grepe uit die geskiedenis van Juda gedurende die tyd toe Assirië die wêreldmag was en Hiskia die koning in Jerusalem, en rangskik en wend dit dan so aan dat dit aan 'n gegewe gehoor gedurende 'n bepaalde tyd 'n bepaalde boodskap oorgedra het.

Die verhaal word deur intertekstuele relasies sowel na binne (Jes 3639) as na buite (Jes 1-35 en Jes 40-66) gebind, en sodoende deel gemaak van die boek Jesaja in sy geheel. Hier word slegs een voorbeeld van interne binding aan die orde gestel, naamlik die herhaling van woorde soos בטח "om te vertrou” (Jes 36:4,5,6,7,9; 37:10) - vergelyk Jenni \& Westermann (1984:303) se uiteensetting van die woord בטח "om te

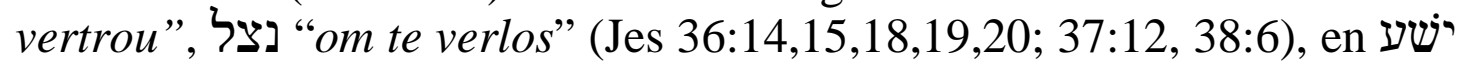
"om te red" (Jes 37:20,35; 38:20). Hiskia moet op Jahwe vertrou en Jahwe sal verlos; Hy wat Jahwe is, sal die koning en die stad red. Sion sal nie tot niet gaan nie.

Die herhaaldelike voorkoms van hierdie teologiese temas bind nie alleen die teks nie, maar gee ook reeds vir die leser 'n aanduiding van die rigting waarin daar gesoek moet word na die boodskap van Jesaja 36-39. Vergelyk byvoorbeeld Alter (1981:93) se belangrike opmerking:

"A Leitwort is a word or a word-root that recurs significantly in a text, in a continuum of texts, or in a configuration of texts: by following these repetitions, one is able to decipher or grasp a meaning of the text, or at any rate, the meaning will be revealed more strikingly".

Verdere binding na binne en na buite sal uit die res van die bespreking duidelik word. 
Uit 'n detaileksegese blyk dat die twee verhale, te wete dié in Jesaja 38, wat handel oor Hiskia se siekte en genesing, en dié in Jesaja 39, wat handel oor die besoek van 'n hoë afvaardiging uit Babel, waarskynlik 'n dieper betekenis het as wat uit 'n oppervlakkige lees sigbaar word. Daar is navorsers, byvoorbeeld Ackroyd (1974) en Watts (1987) - en ek sluit by hulle aan - wat meen dat Hiskia se siekte en genesing onder meer op Juda se Babiloniese ballingskap kan dui, maar ook op uiteindelike herstel onder Persiese bewind. Daarmee word daar nie noodwendig 'n streep getrek deur die historisiteit daarvan nie, maar wil ek aandui dat die wyse waarop (en die konteks waarin) die verhaal aangebied word, moontlik kan dui op 'n teologiese interpretasie deur die redaktor(s) van Hiskia se siekte.

Insgelyks is ook Jesaja 39 gelees in die konteks van die Babiloniese ballingskap. In aansluiting by Ackroyd (1974) is daar gewys op die moontlik diepere betekenis van 'n begrip, soos byvoorbeeld ראה "sien", veral in die lig van die herhaling daarvan. Daar is daarop gewys dat dit moontlik op besitname van die skatte, wapentuig en die land kan dui, en dus die ballingskap op die oog kan hê. Meer voor die hand liggend is egter die verwysings na die ballingskap in Jesaja 39:6-7, sodat daar geen twyfel kan wees oor die feit dat Jesaja 39 die ballingskap op die oog het nie.

Dit blyk dat, hoewel Jesaja 38 en 39 deur bepaalde merkers aan die gebeure wat hom afgespeel het met die Assiriese beleg van Jerusalem in $701 \mathrm{vC}$ gebind word (vgl bv Jes 38:1,5,6 en 39:1), dit egter ook deur gebruikmaking van bepaalde motiewe vorentoe kyk, en dat die Babiloniese ballingskap op die horison verskyn. Daar is dus in die teks ' $n$ subtiele beweging van 'n tyd van Assiriese heerskappy na 'n tyd van Babiloniese heerskappy.

Na my oordeel is dit juis die herrangskikking van gebeure (Jes 36-37, 38 en 39, ipv Jes 38, 39 en 36-37), die doelbewuste koppeling van bepaalde gebeure aan die daaraan voorafgaande gebeure (Jes 38:1 en Jes 39:1), asook die doelbewuste gebruikmaking van belangrike terme in Jesaja 36-39 ( נצל ; בטע en wa ook oor die hele Jesaja versprei is, wat daarop dui dat nóg die boek Jesaja in geheel, nóg Jesaja 36-39 in een sitting deur een persoon op een gegewe plek geskryf is. Die boek Jesaja, maar dan spesifiek ook Jesaja 36-39, het 'n bepaalde redaksionele geskiedenis gehad voordat dit uiteindelik in sy huidige vorm gestol het. Jesaja bestaan uit verskillende tekstuele lae wat oor 'n lang tyd saamgevoeg, oorgewerk en ook bygewerk is. Die eenheid van die teks is daarom net so min absoluut as wat die tradisionele driedeling van die boek absoluut is. 


\section{TERUG NA ('N) HISTORIESE KONTEKS}

Die gevolgtrekkings wat na aanleiding van die historiese en literêre perspektiewe op die teks gemaak is, het aan die lig gebring dat die boek Jesaja, en dan met name Jesaja 38 en 39, eerder 'n teologiese as 'n historiese funksie het (vgl Rendtorff 1988:7). Die historiese konteks geïmpliseer in die teks is egter nie dieselfde as die historiese konteks waarheen die teks die leser verplaas nie. Dus, wanneer daar nou teruggekeer word na 'n historiese konteks, is dit nie weer die agste-eeuse konteks nie, maar die konteks deur die teks geïmpliseer.

\subsection{Die redaksiegeskiedenis van Jesaja 36-39}

Die vraag na die moontlike gehoor van Jesaja 38 en 39 bring die Redaktionsgeschichtliche Fragestellung van die boek Jesaja binne die navorser se gesigsveld. Dit verg geen besondere kennis van die boek om te besef dat die redaksionele en komposisionele geskiedenis van Jesaja 'n heel komplekse en ingewikkelde saak is nie. Byna elkeen wat hom/haar met die boek Jesaja besig hou, verwys daarna ${ }^{4}$. Die skryf van 'n eie Redaktionsgeschichte van óf die boek Jesaja óf 'n deel daarvan, was egter nooit die bedoeling van hierdie studie nie, en gaan ook nie nou aangepak word nie. Trouens, die redaksiegeskiedenis van Jesaja regverdig sonder twyfel 'n studie wat slegs op daardie aspek fokus en niks meer nie. Selfs die skryf van 'n oorsig van resultate wat die redaksiegeskiedenis net tot dusver betref, sal reeds heelwat ruimte in beslag neem.

In hierdie studie val die klem op die historiese en literêre dimensies van Jesaja 38 en 39, en daar gaan met hierdie twee aspekte volstaan word. Daar moet egter wel van die resultate van die Redaktionsgeschichtliche Fragestellung kennis geneem word, omrede daar in die beantwoording van die vraag na die uiteindelike gehoor van Jesaja 38 en 39 ten minste vanuit 'n bepaalde vooronderstelling ten opsigte van die Redaktionsgeschichte van die boek Jesaja uitgegaan sal word. In die opsig vind ek Sweeney (1996) se bondige opmerkings bruikbaar, deurdat dit die belangrikste standpunte in die huidige Redaktionsgeschichtlichedebat verreken.

Sweeney (1996:51) herhaal die nou reeds oorbekende en algemeen aanvaarde standpunt onder Jesajanavorsers oor die metodologiese spektrum, naamlik dat hoewel die boek Jesaja dit self as 'n enkele literêre werk aanbied, detailstudies aan die lig gebring het dat dit 'n saamgestelde werk is met 'n redaksionele geskiedenis wat oor ten minste vier eeue strek. Hy onderskei vier groot fases in die redaksionele proses wat hy soos volg aandui, beginnende by die finale fase: (1) die finale vorm van Jesaja 1-66 wat gestalte gekry het teen die agtergrond van die

\footnotetext{
${ }^{4}$ Vergelyk byvoorbeeld net vir Clements 1985:98 en Darr 1994:225.
} 
grootskaalse hervormings onder Esra en Nehemia in die middel tot laat vyfde eeu $\mathrm{vC}^{5}$; (2) 'n laat sesde-eeuse redaksie van die boek in Jesaja 232; 34-55 en 60-62, wat gestalte gekry het teen die agtergrond van die terugkeer van ballinge uit die Babiloniese ballingskap na Jerusalem en die bou van die tweede tempel ${ }^{6}$; (3)'n laat sewende-eeuse redaksie bestaande uit Jesaja 5-23; 27-32 en 36-37, wat ten doel gehad het om koning Josia van Juda se nasionale en godsdienstige hervormings te ondersteun ${ }^{7}$ en dan (4) verskeie tekste wat regdeur Jesaja 1-32 te vinde is wat teruggevoer kan word na die agste-eeuse profeet, Jesaja ${ }^{8}$.

Belangrik is om daarop te let dat daar 'n groeiende aantal navorsers is wat nie meer aan Proto-, Deutero- en Tritojesaja dink as aanvanklik drie selfstandige versamelings, elk met 'n eie wordingsgeskiedenis, wat later deur een redaktor byeengebring is om een groot profetewerk te verteenwoordig nie ${ }^{9}$. Rendtorff (1985:200) formuleer die groeiende konsensus in dié verband soos volg:

"... the book of Isaiah has not been composed by the combination of three independent "books", but is a work with many strata and a lengthy history behind it"

(Rendtorff 1985:200).

Hoewel alle navorsers nie met die detail van Sweeney se redaksionele rekonstruksie saamstem nie, en selfs enkele fases mag weglaat, kombineer of byvoeg, verteenwoordig dit die huidige konsensus in die breë. So is daar ook al hoe meer stemme wat opgaan ten gunste van die siening dat die finale redaksie van Jesaja 1-66 bedoel was om die hervormings van Esra en Nehemia te steun (vgl oa Sweeney 1996:51 en Koole 1997:37) en dat dit moontlik 'n uitbreiding op die sesde-eeuse redaksie was (vgl oa Sweeney 1996:51 en Blenkinsopp 2000:87).

\subsection{Hervormings onder Esra en Nehemia in die middel tot laat vyfde eeu vC}

Uit byna al die gelese literatuur is dit duidelik dat die gemeenskap in Jerusalem gedurende hierdie tyd, soos trouens die geval was met byna sy ganse geskiedenis, 'n verdeelde gemeenskap was (vgl bv Smith 1987). Hierdie verdeeldheid is deur die hele boek Jesaja sigbaar. Ons vind byvoorbeeld reeds in die agste eeu $\mathrm{vC}$ onder meer 'n pro-Assiriese

\footnotetext{
${ }^{5}$ Vergelyk ook Watts (1985:xxix-xxxii).

${ }^{6}$ Vergelyk byvoorbeeld Blenkinsopp (2000:87).

${ }^{7}$ Vergelyk byvoorbeeld Barth (1977).

${ }^{8}$ Vergelyk byvoorbeeld Kaiser 1984:222 ev.

${ }^{9}$ Vergelyk byvoorbeeld Zenger (1998:313-315) se bespreking van die Entstehung van Jesaja waarin hy ook kortliks aandag gee aan die nuutste gedagterigtings.
} 
party $^{10}$, 'n pro-Egiptiese party (beide hierdie partye was meer sinkretisties van aard) en 'n party wat in die loop van die navorsingsgeskiedenis as die Jahwe-alleen party bekend geword het (Smith 1987:30 ev).

In die vyfde eeu vC het hierdie situasie weinig verander. Dit spreek vanself dat die onderskeie partye en hulle leiers meegeding het om aandag en ondersteuning onder die Judeërs, sowel binne as buite die grense van die Persiese provinsie van destyds. Ons sien as 't ware dat elke faset van Joodse belange op dié wyse gedek word (Watts 1985:xxx). In die literatuur word daar melding gemaak van die groep mense wat sedert die ballingskap in die land agtergebly het, of gedurende dieselfde tyd daarheen getrek het. Daar was diegene wat steeds in ballingskap was, en dié wat teruggekeer het na hulle vaderland Kanaän, of dan die stad Jerusalem. Smith (1987:107) identifiseer laasgenoemde as die Jahwealleen party en voeg die outeur(s)/redaktors(s)/ profetegroep van Jesaja by hierdie Jahwe-alleen party.

Dan was daar nog die priester party ${ }^{11}$ wat verwant was aan die Sadokiete waaruit die belangrikste tempelamptenare in pre-eksiliese tye bestaan het. 'n Laaste groep wat hier dien vermeld te word, het bestaan uit sowel die Dawidiese leiers, leiers uit Samaria as van die omstreke van Juda (Watts 1985:xxx). Ons kan ons dus voorstel dat sowel politieke, godsdienstige, ekonomiese as streeksbelange 'n rol sou gespeel het. Dit is in hierdie diverse gemeenskap met sy onderskeie groepe, leiers en faksies wat Jesaja se boodskap ontvang word en by sommige se gedagtes aansluit, ander tot orde roep en nog ander temper (Watts 1985:xxx).

Hier gaan alleen maar gefokus word op die breër teologiese aspekte van hierdie konflik. Daar gaan nie soseer op elkeen van die onderskeie groepe wat vanuit verskillende perspektiewe op die teks identifiseerbaar is, en reeds geïdentifiseer is, gefokus word nie.

Uit die Bybelse literatuur word die indruk geskep dat die hoop op 'n herstel van die Dawidiese ryk, ten minste wat die vyfde eeu vC betref, eers op die agtergrond geplaas is. Dit het waarskynlik te doen met die voltooiing van die tempel en die byna ongesiene verdwyning van Serubbabel van die toneel in Kanaän, en die feit dat Haggai en Sagaria se profesieë nie gerealiseer het nie. Die latere Makabeër-opstande gedurende die Hellenistiese tyd toon egter aan dat die hoop op politieke herstel nooit heeltemal begrawe is nie.

\footnotetext{
${ }^{10}$ Wanneer Smith (1987:10) van “partye” praat, meld hy dat daar met dié begrip 'n groep van eendersdenkende individue bedoel word, sonder dat dit noodwendig op 'n formeel georganiseerde party of groep dui. In hierdie studie word daar by Smith se definisie aangesluit.

${ }^{11}$ Watts (1985:Xxx) sien die Leviete as deel van hierdie groep, terwyl andere (bv Deist \& Le Roux 1987:153) die Leviete as teenstanders van die priester party sien.
} 
Op sosio-ekonomiese gebied was daar maar altyd spanning en soms selfs konflik tussen ryk en arm, 'n situasie wat gedurende die vyfde eeu $\mathrm{vC}$ ook eerder versleg as verbeter het. Die navorser kry egter die indruk dat selfs dit, ten minste wat die Hebreeuse kanon betref, effe op die agtergrond geskuif is ter wille van 'n baie meer akute konflik, te wete die konflik tussen twee godsdienstige strominge in die vorm van 'n sinkretistiese Jahwe groep en die Jahwe-alleen groep ${ }^{12}$.

Hoewel navorsers, soos byvoorbeeld Smith (1987:81), ten minste nog 'n derde groep identifiseer, te wete die priester party, wat in die besonder ekonomiese belang gehad het in die herbou en bestuur van die tweede tempel, het die godsdienstige debat hom in twee breër strome voltrek, te wete die stryd tussen die Jahwe-alleen party, wat die minderheidsparty was, en die sinkretistiese Jahwe party, wat die meerderheidsparty was (Schramm 1995:179). Ter bevestiging van hierdie standpunt kan daarop gewys word dat Smith (1987:81-82) van mening is dat sommige lede van die priester party hulle aan die kant van die Jahwe-alleen party geskaar het, terwyl ander lede van die priester party hulle weer aan die kant van die sinkretistiese Jahwe party, soos onder meer blyk uit hulle huwelike met vreemdelinge, geskaar het. Tussen die Jahwe-alleen party en die priester party was daar tot 'n mindere of meerdere mate van samewerking sprake (Smith 1987:84-85), en dit laat ons dan basies met die Jahwe- alleen party versus die sinkretistiese Jahwe party ${ }^{13}$.

In hierdie konflik gedurende die na-eksiliese tyd, en dan veral gedurende die tweede tempel-periode, was een van die groot vrae: Wie is nou eintlik die ware "volk van Jahwe"? Is dit die aanhangers van die sinkretistiese Jahwe party, of is dit die aanhangers van die Jahwe-alleen party?

\subsection{Sinkretisme versus monoteïsme}

Wanneer 'n mens die boeke van Esra en Nehemia lees, is dit duidelik dat volgens hulle dit die "volk van Jahwe" was wat in ballingskap weggevoer is en dat dit die "volk van Jahwe" is wat uit ballingskap teruggekeer het (Schramm 1995:58). Dié wat uit die ballingskap teruggekeer het, word die בני הגולה genoem (letterlik: “die kinders van die ballingskap”), terwyl diegene wat die ballinge met hulle terugkeer na Kanaän in die land

\footnotetext{
${ }^{12}$ Dit is belangrik om in aansluiting by Smith (1987:11-24) net weer daarop te wys dat daar ten minste reeds in die monargale tyd spanning was tussen die sinkretistiese Jahwe party en die Jahwe-alleen party.

${ }^{13}$ Hierdie standpunt is kontra Hanson (1975:409) wat die Sadokitiese priester party uitsonder as die "vyand" van die outeurs/redaktors van Jesaja, die Leviete en ander minderheidsgroepe. Waaroor daar egter wel tot 'n groot mate eenstemmigheid in die literatuur is, is dat diegene wat die sinkretistiese Jahwisme teengestaan het minderhede en selfs tot 'n groot mate randfigure was.
} 
gevind het, die עם הארץ genoem word (letterlik: "die volk van die land"). Esra en Nehemia se grootste kommer was 'n vermenging van עם הארץ met Anders gestel: hulle was bekommerd dat diegene wat, soos hulle, Jahwe alleen aanbid, deur ondertrouery met aanhangers van die sinkretistiese Jahwe-geloof, self ook in sinkretisme sal verval.

Ons sou dus Esra en Nehemia onder die vaandel van die Jahwe-alleen party kon plaas (Smith 1987:92, 110) en hulle het teenoor die

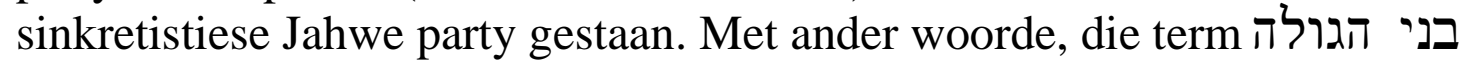
en die term עם הארץ het teologiese terme geword. Almal wat aan Jahwe alleen vasgehou het, en dus Esra se wet aanvaar het, het onder die vaandel van die בני הגולה beweeg. Dit kon dus, en het na alle waarskynlikheid wel, mense ingesluit wat nooit eens in ballingskap was nie, terwyl daar van die ballinge kon wees wat deur byvoorbeeld ondertrouery met הארץ vauens uit die sinkretistiese Jahwisme beskou is as deel van die עם (Schramm 1995:61).

Volgens Smith (1987:88) het die sinkretistiese Jahwe party aanvanklik, na die bou van die tweede tempel, die beheer onder die Jode in Kanaän gehad. Verwysings na afgodsdiens in onder meer Tritojesaja en Sagaria bevestig die standpunt (Smith 1987:88). Deur die werk van Esra en Nehemia het die Jahwe-alleen party egter langsamerhand húlle vorm van die Jahwekultus laat deursyfer na die bevolking in die algemeen totdat hulle uiteindelik die oorhand in Juda gekry het en dit die karakter van 'n nasionale godsdiens aangeneem het (Smith 1987:110). Hierdie proses is deur die sukses van die Makabeëropstande versnel, maar het hom tog eers gedurende die christelike era voltrek (Smith 1987:62-63). Uit die aard van die saak is alle teenstand hiermee nie uit die weg geruim nie (Smith 1987:110), maar die Jahwe-alleen party het die pas aangegee (Schramm 1995:181-182), en hulle tradisie het uiteindelik die finale vorm van die Hebreeuse kanon sterk beïnvloed (Albertz 1992:534 ev en Smith 1987:1-10).

\section{ENKELE VOORLOPIGE GEVOLGTREKKINGS}

Die indruk wat deur die teks geskep word, is dat die redaktor(s) van Jesaja drie verhale wat in die agste eeu vC afspeel, neem, dit herrangskik en in 'n bepaalde literêre konteks plaas. Deur dié verhale uit hulle historiese konteks te neem, lyk dit asof die redaktor(s) sy/hulle hoorder(s)/leser(s) doelbewus aan die betrokke tyd wil herinner.

Hulle moes onthou hoe die Assiriese koning, Sanherib, Jahwe gespot het, maar hoe hy uiteindelik in die tempel van sy eie god om die lewe gebring is. Hulle moes die feit dat die magtige Assiriese leër toe nooit Jerusalem kon inneem nie, in herinnering roep. Hulle moes hulself 
herinner hoe Jahwe die lewe van die Judese koning van dié tyd, naamlik Hiskia, verleng het.

Die redaktor(s) wil waarskynlik hê dat hulle hoorder(s)/leser(s) Hiskia moes sien as 'n vrome koning wat, op aandrang van die profeet Jesaja, volledig en uitsluitlik op Jahwe vertrou het in sowel 'n nasionale as 'n persoonlike krisis. Op grond van hierdie absolute vertroue op Jahwe, en Hom alleen, is hy in sowel sy persoonlike as amptelike hoedanigheid verlos, en het hy in 'n danklied aan God al die eer gebring. Ja, hulle moes onthou dat die stad en die koningshuis in 'n krisistyd deur hulle trou aan Jahwe, en aan Jahwe alleen, deur Hom verlos is.

Hulle moes ook onthou hoedat een van die sterk konings van destyds, naamlik Merodag-Baladan, 'n afvaardiging van hoë amptenare na die koning van Juda gestuur het, maar hoe Hiskia se ydelheid daartoe gelei het dat die profeet in die naam van Jahwe aangekondig het dat alles wat die Babiloniese afvaardiging gesien het, na Babel weggevoer sou word. Die woord van Jahwe by monde van sy profeet is vervul. Daarvan is hulle immers getuie. Hulle het die ballingskap self beleef.

Die redaktor(s) het Jesaja 36-39 in 'n heel spesifieke literêre konteks geplaas, en dit deur bepaalde merkers en motiewe met die res van die boek Jesaja verbind. Jesaja 38 en 39 word net voor Jesaja 40 ev geplaas, wat duidelik die eksiliese en selfs na-eksiliese tyd as historiese agtergrond het. Ons meen dat dit doelbewus so gedoen is. Die redaktor(s) wil op dié wyse vir sy/hulle gehoor hoop gee in moeilike omstandighede en/of vir die toekoms. Indien ons aanvaar dat die finale redaksionele prosesse eers in die na-eksiliese tyd afgehandel is, en dit is na ons mening die geval, dan lyk dit of die redaktor(s) aan hulle gehoor/leser(s) 'n boodskap van hoop wou bring. Die hoorder(s)/leser(s) moes raaksien dat Jahwe in die verlede op 'n wonderbaarlike wyse in die volk en die koning se lewe ingegryp het. Hulle moes raaksien dat Jahwe deur sy profeet Jesaja die Babiloniese ballingskap aangekondig het. So kondig Hy nou weer deur sy profeet aan dat die uitkoms op hande is. Hulle moes weet dat, soos daar in die verlede vir koning en stad herstel was, so lê daar ook vir hulle nou herstel voor. Hulle kon maar op die woorde van die profeet van hulle dag vertrou. Bo alles moes hulle op Jahwe en op Hom alleen vertrou. Hy is by magte om te verlos.

\section{DIE BOODSKAP VAN JESAJA 36-39}

Uit die navorsing het dit geblyk dat dit in Jesaja 36-39 oor vertroue op Jahwe in krisistye gaan. Die een wat Hom vertrou, kan reken op verlossing en herstel; hy kan Jahwe weer in sy tempel aanbid (Jes 38). Daar is egter 'n bedekte waarskuwing oor die vertroue in mense, of dit nou 'n vreemde volk is (Babel), of 'n Dawidiese koning (Hiskia). Op 
mense moet die gelowige sy hoop nie plaas nie, want dit lei tot ondergang (Jes 39). Ja, Jahwe gebruik mense as instrumente, maar die gelowige se vertroue moet steeds in Hom setel.

Vir die gemeenskap in die tyd van Esra en Nehemia kon Jesaja 36-39 dus moontlik die volgende boodskap gedra het:

- Hulle moes op Jahwe en hom alleen vertrou, want Juda se heil lê nie by vreemde volke nie (vgl die verwysings na Egipte en Babel), maar in vertroue op Jahwe alleen. Hy bring herstel en verlossing (vgl die bevryding van die stad en Hiskia se herstel van siekte).

- Selfs nie die koning, die gesalfde van Jahwe, kan die verlossing bring wanneer hy Jahwe vergeet nie, want Hiskia, van wie so baie verwag is, het ook maar teleurgestel - hy was nie die een wat sou kom nie (vgl sy hubris in teenwoordigheid van die Babiloniese afvaardiging).

- Jahwe sal hulle verlos, Hy sal hulle herstel en hulle sal Hom weer in die tempel aanbid.

Hierdie boodskap sou vir die mense van destyds nie alleen troos gebring het nie, maar sou ook 'n duidelike rigtingwyser gewees het.

\section{Literatuurverwysings}

Ackroyd, P R 1974. An Interpretation of the Babylonian Exile: A Study of 2 Kings 20, Isaiah 38-39. SJT 27, 329-352.

Albertz, R 1992. Religionsgeschichte Israels in alttestamentlicher Zeit. Teil 2. Göttingen: Vandenhoeck.

Alter, R 1981. The Art of Biblical Narrative. New York: Basic Books Inc. Publishers.

Barth, H 1977. Die Jesaja-Worte in der Josiazeit. Neukirchen-Vluyn: Neukirchener Verlag.

Blenkinsopp, J 2000. Isaiah 1-39. AB. Doubleday: Anchor Bible.

Brink, A P1987. Vertelkunde: ' $n$ Inleiding tot die lees van verhalende tekste. Kaapstad: Academica.

Clements, R E 1985. Beyond Tradition-History: Deutro-Isaianic Development of First Isaiah's Themes. JSOT 31, 95-113.

Conrad, E W 1991. Reading Isaiah. Minneapolis: Fortress Press.

Darr K P 1994. Isaiah's vision and the family of God. Louisville: Westminster.

Deist, F E \& Le Roux, J H 1987. Rewolusie en Reïnterpretasie. Die Literatuur van die Ou Testament, Deel 4. Kaapstad: Tafelberg Uitgewers.

Deist, F E 1995. On 'Synchronic' and 'Diachronic': Wie es eigentlich gewesen. JNSL 21/1, 37-48.

Exum, J C \& D J A Clines 1993. The New Literary Criticism and the Hebrew Bible. JSOTSS 143. Sheffield: Sheffield Academic Press.

Hanson, P 1975. The Dawn of Apocalyptic. Philadelphia: Fortress Press. 
Human, D J 1999. Die literêr-historiese lees van 'n teks. Skrif en Kerk 20/2, 354-368.

Jenni, E \& C Westermann 1984. Theologisches Handwörterbuch zum Alten Testament. (Zwei Bände) Band I. Zürich: Theologischer Verlag.

Kaiser, O 1984. Introduction to the Old Testament: A Presentation of its Results and Problems. Oxford: Blackwell.

Kasher, R 2001. The Sitz im Buch of the Story of Hezekiah’s Illness and Cure (II Reg 20,1-11; Isa 38,1-22.) ZAW 113/1, 41-55.

Koole, J L 1997. Isaiah III. (Volume 1/Isaiah 40-48). Kampen: Pharos.

Le Roux, J H 1993. A Story of two Ways. Old Testament Essays Supplement Number 2, Pretoria: Verba Vitae Publishers.

Melugin, R F \& M A Sweeney (eds), 1996. New Visions of Isaiah. JSOTS 214. Sheffield: Sheffield Academic Press.

Rendtorff, R 1985. The Old Testament: An Introduction. London: SCM Press.

Rendtorff, R 1988. How to read Isaiah 1-39 against its historical background: Some hermeneutical reflections. OTE 1/3, 1-10.

Schramm, B 1995. The Opponents of Third Isaiah. Reconstructing the Cultic History of the Restoration. JSOTS 193. Sheffield: Sheffield Academic Press.

Smith, M 1987. Palestinian Parties and Politics that Shaped the Old Testament. New York: Columbia University Press.

Snyman, S D 1996. 'n Struktureel-historiese benadering tot die eksegese van die Ou Testament. NGTT. XXXVII (4), 540-549.

Sweeney, M A 1988. Isaiah 1-4 and the Post-Exilic Understanding of the Isaianic Tradition. (BZAW 171) Berlin: De Gruyter.

-, 1996. Isaiah 1-39 with an introduction to prophetic literature (FOTL 16). Michigan: Eerdmans.

Watts, J D W 1985 Isaiah 1-33 (WBC Vol 24). Waco: Word Books, Publisher.

-, 1987. Isaiah 34-66 (WBC Vol 25). Waco: Word Books, Publisher.

Wildberger, H 1982. Jesaja. Kapitel 28-39. (BKAT X3). Neukirchen-Vluyn: Neukirchener Verlag.

Zenger, E (u.a.) 1998. Einleitung in das Alte Testament. (Studienbücher Theologie Band 1,1) Dritte, neu bearbeitete und erweiterte Auflage. Stuttgart: Kohlhammer. 